\title{
DESAIN DEKORATIF KAMPUNG KOTA SEBAGAI WACANA ALTERNATIF DALAM KEHIDUPAN SOSIAL-POLITIK
}

\author{
Bernardus Andang Prasetya Adiwibawa ${ }^{1}$, Deddy Award W. Laksana ${ }^{2}$ \\ ${ }^{1}$ Prodi Desain Komunikasi Visual, Fakultas IImu Komputer \\ ${ }^{2}$ Prodi Animasi, Fakultas IImu Komputer \\ Universitas Dian Nuswantoro, Jl. Imam Bonjol 207 Pendrikan Kidul, Semarang - Jawa Tengah \\ email: ${ }^{1}$ andangprast@dsn.dinus.ac.id, 22deddyawardwidyalaksana@gmail.com
}

\begin{abstract}
Abstrak: Desain dekoratif Kampung Kali Code, menjadi fenomenal di era 1980an dan menjadi awal desain dekoratif kampung dengan warna-warni yang mencolok saat ini. Kampung-kampung kota yang kemudian mengikuti model desain dekoratif Kampung Kali Code baru muncul kemudian setelah 25 tahun, dialah Kampung Warna-warni Jodipan di Malang dan Kampung Pelangi Wonosari di Semarang. Penelitian ini mencoba menjelaskan hubungan antara desain dekoratif kampung kota dan dinamika sosial-politik yang melingkupi suatu masyarakat. Unit penelitian ini adalah tiga kampung kota; Kampung Kali Code di Yogyakarta, Jodipan di Malang dan Wonosari di Semarang. Metode yang digunakan dalam penelitian ini adalah metode penelitian kualitatif dengan menggunakan analisis wacana. Melalui analisis wacana tersebut, penelitian ini menunjukkan bahwa desain dekoratif kampung kota dapat menjadi wacana alternatif dalam konteks dinamika sosial politik yang berkembang di Indonesia pada kurun 2016-2018.
\end{abstract}

Kata kunci: Desain Dekoratif, Kampung Kota, Sosial-Politik

\begin{abstract}
Kampong Kali Code's decorative design has become phenomenal in the 1980s and been the beginning of the kampong's decorative design with striking colors today. Other urban kampongs which followed the decorative design model of the Kampong Kali Code emerged later after 25 years, they are the Colorful Kampong of Jodipan in Malang and Rainbow Kampong of Wonosari in Semarang. This study tries to explain the relationship between kampong's decorative design and the dynamics of socio-political surrounding a community in those three urban kampongs. The research units are Kampung Kali Code in Yogyakarta, Jodipan in Malang and Wonosari in Semarang. The method used in this research is qualitative one using discourse analysis. Through discourse analysis, this study shows that the decorative design of urban villages can be an alternative discourse in the context of developing socio-political dynamics in Indonesia in 2016-2018.
\end{abstract}

Keywords: tourism, destination branding, digital destination, Ketenger Tourism Village 


\section{PENDAHULUAN}

Desain dekoratif suatu kampung kota, yang fenomenal pada dekade 1980an, adalah desain Kampung Kali Code, Yogyakarta. Mangunwijaya, dikenal juga sebagai Romo Mangun, seorang rohaniwan dan budayawan, bersama sekelompok anak muda yang menjadi relawan sosial bekerja bersama masyarakat yang tinggal di bantaran Kali Code, dalam rangka memperbaiki kualitas infrastruktur fisik dan sosial di kampung itu (Sunaryo; 2007, Hanum; 2011, Handayani; 2012).

Romo Mangun dengan dibantu kelompok relawannya sungguh berpengaruh pada desain dekoratif Kampung Kali Code. Puspitasari, dkk. (2013) menyatakan bahwa karakter visual permukiman Kampung Kali Code yang dipengaruhi oleh karakter Mangunwijaya nampak pada: skala bangunan, bentuk, pola garis, proporsi, tekstur dan warna.

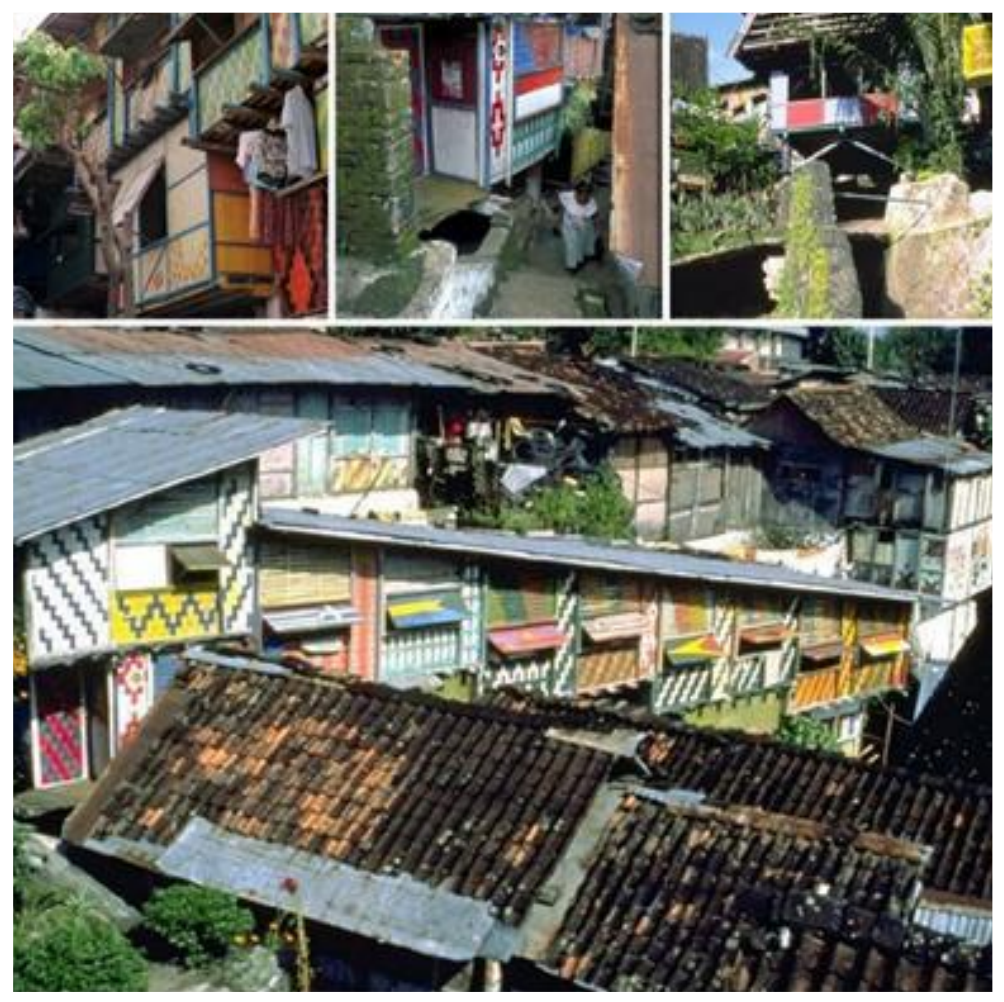

Gambar 1. Kolase beberapa sudut Kampung Kali Code Sumber : dokumen pribadi 
Terkait dengan penggunaan warna dalam desain dekoratif kampung ini, Romo Mangun dan kelompoknya berusaha menarik perhatian penduduk Yogyakarta pada umumnya dan khususnya siapa saja yang melintas di atas Jembatan Gondolayu yang tepat berada di sisi utara Kampung Kali Code. Ringkasan ulasan teknis untuk penghargaan arsitektur Aga Khan Awards, yang ditulis oleh Radi (1992) menyatakan bahwa penggunakan cat warna-warni dalam desain dekoratif Kampung Kali Code juga merupakan sebuah strategi agar pemerintah Kota Yogyakarta menerima keberadaan kegiatan yang dilakukan oleh Romo Mangun dan kelompoknya beserta penduduk kampung. Sungguh, pada tahun 1980 hingga 1990, Kampung Kali Code terkenal sebagai kampung warnawarni di Yogyakarta.

Pasca penganugerahan Aga Khan Award untuk kegiatan Romo Mangun dan kelompoknya di kampung Kali Code pada dekade 1990an, dapat dikatakan tidak ada lagi berita tentang bagaimana kampung seperti Kampung Kali Code dengan dekorasi cat warna-warni dibuat sebagai strategi untuk meyakinkan atau menyesuaikan dengan program pemerintah. Sekitar 25 tahun kemudian, kabar yang kemudian menjadi viral, adalah munculnya Kampung Warna-warni Jodipan di Malang. Kampung ini menjadi berita di mana-mana, baik di media sosial maupun media arus utama.

Di kota yang lain, Kota Semarang, nyaris pada saat yang bersamaan dengan Kampung Jodipan, Malang, dalam rangka program perbaikan beberapa kampung kumuh yang dicanangkan oleh pemerintah kota, muncul kampung yang juga menjadi viral di berbagai media. Kampung itu adalah Kampung Wonosari, yang lebih populer dikenal sebagai Kampung Pelangi. Letaknya di jantung Kota Semarang, dekat dengan pusat pemerintahan kota ini.

Ada hal yang menarik dari fenomena munculnya karya dekoratif kampung kota di ketiga kampung di atas. Setelah dekade 1980an dan jeda panjang tanpa kabar, pada tahun 2016-2017 muncul lagi berita dan menjadi viral karya dekoratif 
kampung kota. Tulisan ini akan menunjukkan bagaimana dinamika sosial politik itu ditangkap, direfleksikan dan diekspresikan oleh suatu masyarakat dalam suatu karya desain; dalam hal ini karya dekoratif kampung kota.

\section{METODE PENELITIAN}

Unit penelitian ini adalah tiga kampung kota yang didesain dengan dekorasi warna-warni. Masing-masing adalah Kampung Kali Code di Yogyakarta, Kampung Warna-Warni Jodipan di Malang dan Kampung Wonosari - atau Kampung Pelangi di Semarang. Masing-masing dideskripsikan dalam beberapa aspek; sejarah munculnya desain dekoratif masing-masing kampung, konteks sosial politik yang melingkupi munculnya desain dekoratif ini dan pengaruh timbal balik kehadiran kampung-kampung ini dalam dinamika sosial politik masyarakat.

Penelitian ini memakai analisis wacana sebagai alat analisisnya. Pertimbangannya adalah pertama, bahwa kampung-kampung kota yang menjadi unit analisis dapat dipandang sebagai sebuah teks yang hendak dibaca. Kedua bahwa sebagai satu dari sekian banyak alat analisis dalam kajian budaya (Putra, 2013), analisis wacana akan membantu kita mengungkap motivasi-motivasi tersembunyi dari teks tersebut (Ida, 2014).

Secara khusus, analisis wacana yang digunakan adalah analisis wacana kritis (Critical Discourse Analysis/ CDA) sebagaimana yang dianjurkan oleh Norman Fairclough (Hamad, 2017). Tahap analisis Fairclough dimodelkan dalam gambar berikut: 


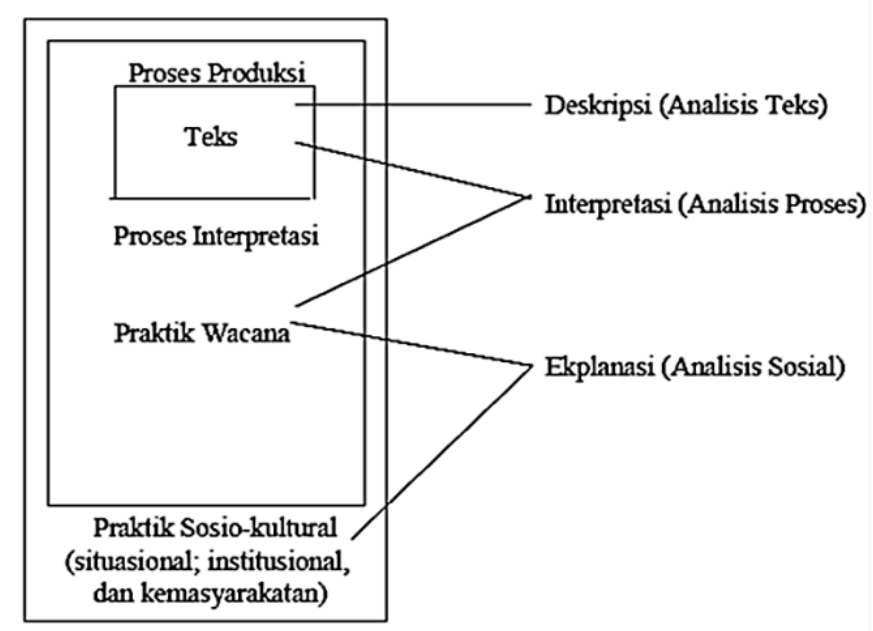

Gambar 2 : Model CDA Norman Fairclough

Dengan model Fairclough, desain dekoratif kampung adalah teks yang harus dideskripsikan (latar historisnya dan aktor-aktor utama) kemudian diinterpretasi proses terjadinya teks tersebut dan selanjutnya dijelaskan dalam praktek wacana (relasi para aktor, situasi sosial politik, ekonomi dan kelembagaannya)

Sumber utama data yang digunakan dalam penelitian ini berasal dari data sekunder. Data tersebut dikumpulkan dari berbagai berita, baik di media sosial maupun media mainstream, buku-buku dan artikel-artikel. Data tersebut kemudian diketegorikan dalam kelompok-kelompok, dipaparkan dan ditafsirkan sesuai dengan perangkat dalam analisis wacana.

\section{KLARIFIKASI KONSEP}

Konsep tentang desain dekoratif sengaja digunakan untuk membedakan dengan mural yang sudah umum. Pertimbangannya adalah, bahwa mural secara leksikal terkait dengan dinding dan langit-langit yang relatif luas; sebagaimana disebutkan dalam kamus merriam-webster untuk entri kata mural. Dalam kamus 
itu pula secara spesifik dalam konteks seni disebutkan bahwa mural adalah lukisan yang diaplikasikan pada dinding dan atau langit-langit.

Dalam beberapa kajian juga disebutkan bahwa mural adalah gambar atau lukisan di atas media dinding yang relatif luas, cukup efektif untuk memberi dampak pada siapa saja yang melihatnya, melalui pesan-pesan yang tergambar (Endriawan, et.al, 2017). Pendapat yang sama diungkap oleh Laksana dan Adiwibawa (2018) yang mengkaji mural dalam konteks kedekatan sosiologis penciptaannya dan dampak sebagai media edukasi.

Sementara dalam beberapa hal, dekorasi (lukisan atau sekadar cat saja) yang ada di Kampung Kali Code, Yogyakarta; Kampung Warna-Warni Jodipan, Malang dan Kampung Pelangi Wonosari, Semarang tidak hanya diaplikasikan pada dinding dan langit-langit saja. Lukisan atau sekadar cat dekoratif juga diaplikasikan pada benda-benda lain; pot bunga, armatur lampu, bola-bola plastik yang digantung, langkan dan pagar dan lain-lain. Alasan inilah yang membuat digunakannya istilah desain dekoratif kampung kota.

\section{HASIL DAN DISKUSI}

\section{a. Sejarah Singkat Masing-masing Kampung}

Kampung Kali Code, terletak di bantaran curam Kali Code, Kota Yogyakarta (Gambar 3). Wilayahnya dibatasi oleh Jembatan Gondolayu di sebelah utara dan pertigaan JI. Faridan M. Noto - Jl. Prau di sebelah selatan.

Lokasi yang sekarang adalah Kampung Kali Code, dulunya adalah tanah kosong di bantaran Sungai atau Kali Code yang curam. Orang mulai menempati bantaran kali ini sejak berakhirnya turbulensi politik di tahun 1950an. Mereka yang tinggal adalah orang-orang yang dianggap sampah masyarakat (Radi, 1992); karakter masyarakatnya miskin dan kualitas permukimannya kumuh (Ayodiya, 2014). 


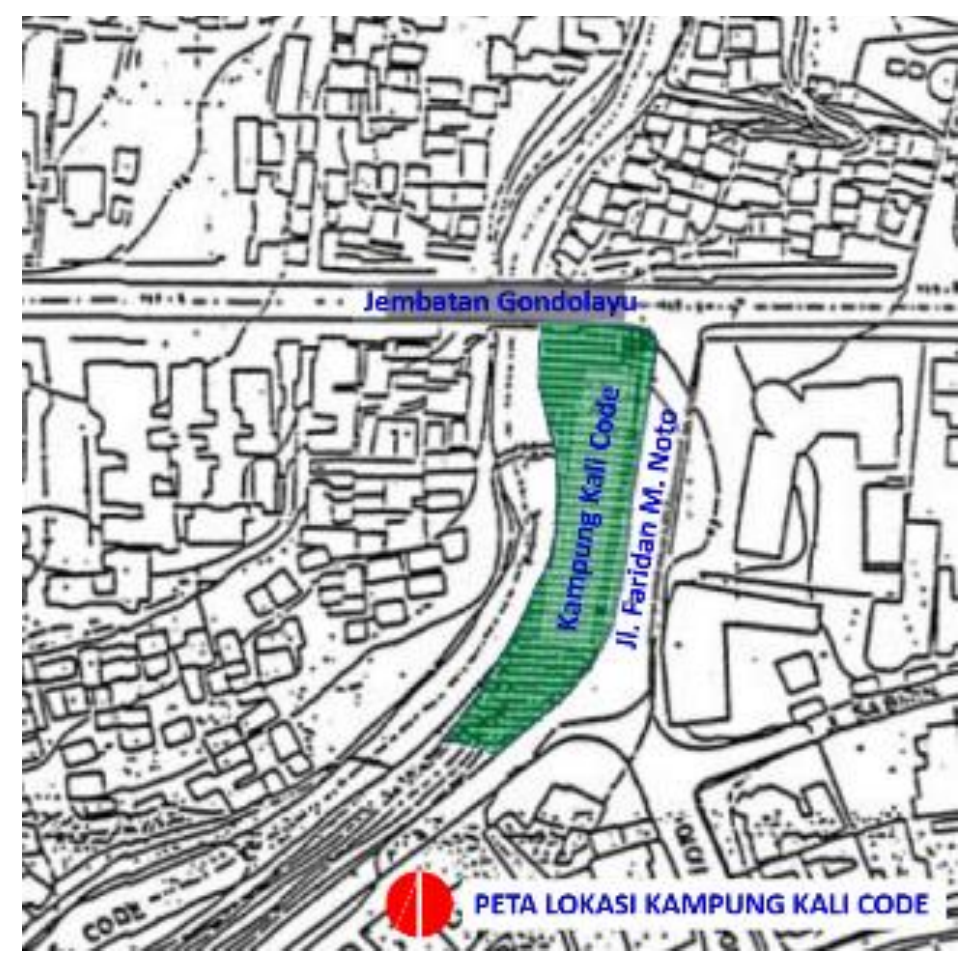

Gambar 3. Lokasi Kampung Kali Code

Sumber : penyuntingan digital dari peta pada http://membacaruang.com

Mirip dengan kampung Kali Code, Kampung Jodipan (Gambar 4) di Malang tumbuh di bantaran sungai, tepatnya Kali Brantas yang melintasi Kota malang. Lokasinya di sisi sebelah timur Jembatan Kali Brantas di Jalan Gatot Subroto. Warga kota Malang, mengenal kawasan ini sebagai Embong Jembatan Brantas (Taufiqurrahman, 2016). Rumah-rumahnya terletak pada tebing bantaran kali, dengan jalan setapak yang sempit, berliku dan sering kali berundak menanjak.

Menurut Hudiyanto (2007), Jodipan adalah sebuah kampung bersejarah di Kota Malang. Toponame kampung ini berasal dari kata Jawa Dwipa. Hudiyanto menyatakan bahwa menurut sejarah populer, awal mula Kampung Jodipan adalah sebuah kampung tua dimana dahulu para pangeran pemberontak dan pasukannya di bawah pimpinan Untung Surapati membangun permukiman. Kemudian turun temurun permukiman itu berkembang hingga saat ini. 


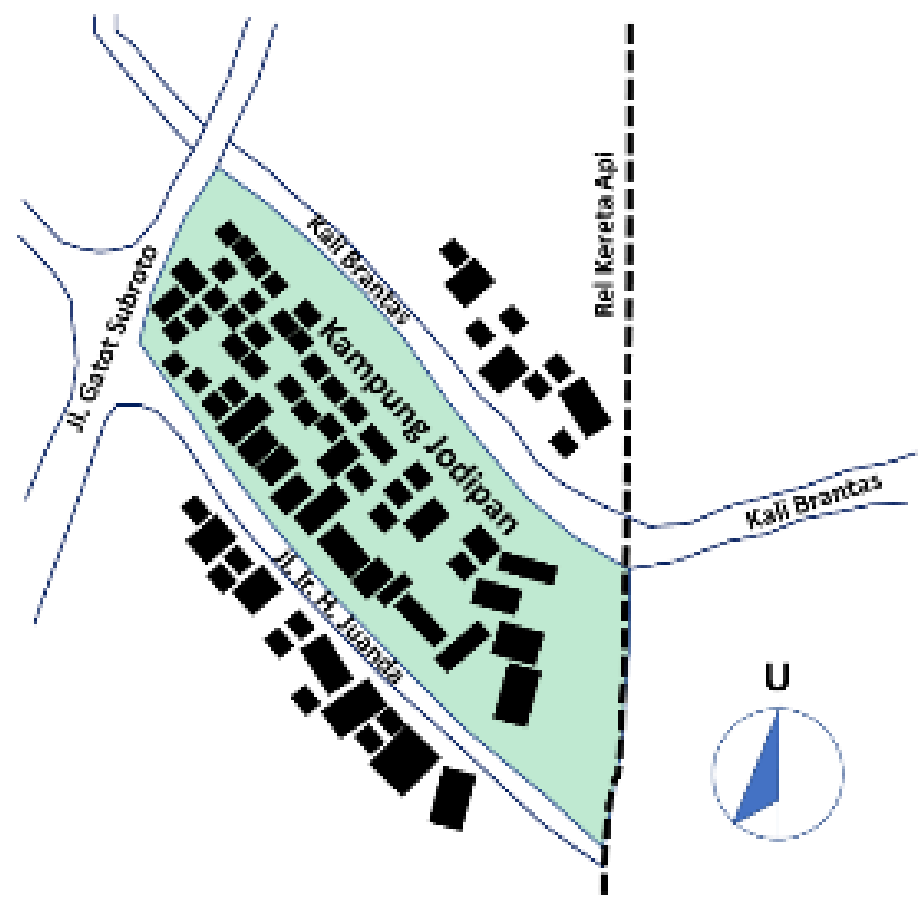

Gambar 4. Lokasi Kampung Jodipan

Sumber: penyuntingan digital dari peta pada Wulandari (2017)

Sama seperti kedua kampung yang disebutkan terdahulu, Kampung Wonosari atau yang populer disebut Kampung Pelangi adalah kampung di tengah kota. Letaknya dapat dikatakan tepat bersebelahan dengan kawasan pusat Kota Semarang di daerah yang dikenal dengan Tugu Muda. Letak kampung ini juga di lahan yang dengan kemiringan curam di tepi sungai atau kali kecil. Perbedaannya dengan Kampung Code dan Kampung Jodipan adalah lahan Kampung Pelangi berada di perbukitan yang secara geologis merupakan tanah asli Kota Semarang (Sudaryanto dan Wibawa, 2013). Kampung ini masuk dalam wilayah deretan perbukitan Bergota dan ada pada wilayah Kelurahan Randusari. Bukit tempat kampung ini berada dikenal dengan sebutan Gunung Brintik, sehingga Kampung Wonosari dikenal pula sebagai Kampung Gunung Brintik. 
Sohirin (2010) dalam laporannya untuk tempo.co menyebutkan bahwa Kampung Wonosari sejak lama ada dan pada periode 1980-1990an terbentuk suatu komunitas yang sebagian besar adalah masyarakat pendatang. Krisis moneter 1997 yang memukul Indonesia membuat sebagian besar para pendatang ini berubah profesi dari pedagang kecil menjadi pekerja serabutan jalanan: pengamen, pemulung dan pengemis.

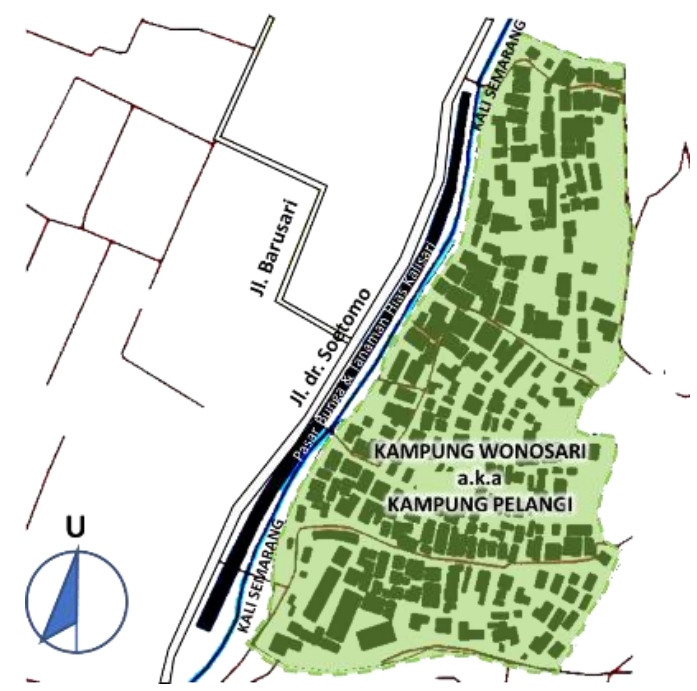

Gambar 5. Lokasi Kampung Pelangi - Wonosari

Sumber : penyuntingan digital dari peta pada Istiana (2018)

\section{b. Kampung Kali Code, Mangunwijaya dan Rezim Orde Baru}

Orde Baru berada pada puncak kekuasaannya pada saat Mangunwijaya, rohaniwan, arsitek, penulis dan budayawan, bersama sekelompok mahasiswa memulai rekayasa sosial dan fisik di Kampung Kali Code. Legowo, dkk (2013) menyebutkan bahwa Orde Baru adalah rezim yang merupakan antitesa Orde Lama. Rezim ini mengedepankan ideologi pembangunanisme, bersifat monolitik dan sentralistik, yang salah satu ekses negatifnya adalah urbanisasi yang masif di Indonesia. Kampung Kali Code adalah salah satu produk dari urbanisme itu.

Pada tahun-tahun pertama dekade 1980an, Mangunwijaya mulai terjun ke Kampung Kali Code atas undangan Lurah Terban saat itu Willi Prasetyo (Radi, 
1992); Kampung Kali Code ada dalam wilayah Kelurahan Terban. Berdua, mereka kemudian dibantu oleh sekelompok anak muda, mahasiswa dan pemuda, sebagai relawan. Dalam melakukan kegiatannya, Mangunwijaya, demi mendapat pengakuan dan penerimaan warga Kampung Kali Code, memindahkan tempat tinggalnya di salah satu rumah di kampung itu (Pakpahan, 2017; Wahono, 2017). Apa yang dilakukan oleh Mangunwijaya untuk tinggal bersama warga menjadi penting, karena dengan demikian menumbuhkan kepercayaan (trust) yang adalah modal penting dalam interaksi sosial (Hanum, 2011).

Kepercayaan pada sosok fasilitator sosial seperti Mangunwijaya, Willi Prasetya dan kelompok relawan di Kampung Kali Code penting ditumbuhkan di kalangan masyarakat. Situasi sosial politik di puncak kekuasaan rezim Orde Baru memunculkan tantangan yang kompleks. Rencana normalisasi sungai, di mana Kali Code adalah salah satu sasarannya, sempat membuat warga kampung khawatir. Radi (1992) menuliskan bahwa Mangunwijaya pun merasa khawatir, jika kegiatannya dikaitkan dengan komunisme, istilah yang sering disematkan oleh rezim Orde Baru kepada semua kegiatan yang dianggap melawan kebijakan rezim.

Berbekal hubungan baik dengan petinggi militer di Yogyakarta, Mangunwijaya menyampaikan semua rencana dan pelaksanaan kegiatan di Kampung Kali Code. Pada tahun 1985, Radi mencatat bahwa rencana pemerintah Kota Yogyakarta untuk menggusur Kampung Kali Code tetap berlanjut, bahkan Lurah Terban, Willi Prasetya ditekan untuk mewujudkan rencana itu. Willi Prasetya dengan berani meminta waktu agar pemerintah melihat hasil kegiatan yang dilakukan Mangunwijaya dan relawannya.

Mangunwijaya dan relawan di Kampung Kali Code bersama masyarakat selain mengorganisasi dan memperkuat kehidupan sosial menjadi lebih baik, juga melakukan rekayasa fisik dalam bentuk penataan permukiman, termasuk mendekorasi rumah dan fasilitas sosial dengan warna-warna yang menarik. Pendekatan rupa dalam dekorasi kampung yang digunakan oleh Mangunwijaya, 
para relawan dan warga kampung dimaksudkan untuk menarik perhatian orang yang melintas Jambatan Gondolayu, di sisi utara Kampung Kali Code. Hasilnya, Kampung Kali Code menjadi point of view yang dominan dalam bentang alam Kali Code dari atas jembatan itu (Adiwibawa, 2017). Kampung Kali Code yang awalnya berkesan kumuh dan ilegal, menjadi sesuatu yang menarik perhatian.

\section{c. Kampung Warna Warni Jodipan, GuysPro dan Pemerintah Kota Malang}

Dekorasi warna-warni Kampung Jodipan yang berada di bantaran curam Kali Berantas, harus dikaitkan dengan GuysPro. Aminudin (2016) dalam laporannya untuk detik.com mengatakan bahwa GuysPro, kependekan dari Guys of Public Relation yang dipimpin oleh Nabila Firdausiyah, adalah kelompok mahasiswa Program Studi IImu Komunikasi di Universitas Muhammadiyah Malang (UMM).

Didorong oleh kebutuhan untuk memenuhi tugas dalam mata kuliah Event Public Relation, kelompok mahaasiswa ini kemudian membuat kegiatan yang melibatkan masyarakat dengan menggandeng korporasi. Maka muncul ide untuk membuat kampung yang semula terkesan muram, didominasi dengah warnawarna tanah yang datar dan membosankan, menjadi luar biasa penuh warna (Adiwibawa 2017).

Korporasi yang digandeng GuysPro dalam pekerjaan di Kampung Jodipan adalah PT. Indana. Dalam situs resmi korporasi ini, www.indana.co.id pada laman Kampung Warna Warni di Kota Malang, disebutkan bahwa pekerjaan ini selesai dan diresmikan pada 4 September 2016. Persemian kampung yang kemudian dinamai secara resmi Kampung Warna-warni Jodipan, dihadiri oleh Wali Kota Malang Mochamad Anton, Rektor UMM, Dr. H. Fauzan, M.Pd, Perwakilan PT Indana, Steven Antonius dan Komandan Yonko Paskhas AU, Malang.

Mengenai dekorasi Kampung Warna-warni Jodipan, Taufiqurrahman (2016) mengatakan bahwa Pemerintah Kota Malang sedikti ketinggalan untuk 
terlibat dalam pekerjaan dekorasi ini. Wali Kota Malang, Mochammad Anton baru mendengar kabar bahwa Kampung Jodipan viral di media sosial pada acara Musyawarah Nasional (Munas) Asosisiasi Pemerintah Kota Seluruh Indonesia (Apeksi) di Jambi 26-28 Juli 2016. Dia mendapat kabar dari Bima Arya Sugiarto, Wali Kota Bogor. Segera selesai munas tersebut, dia mengunjungi lokasi dan bersama aparat pemerintah kota menyusun rencana lebih jauh untuk menjadikan Kampung Jodipan sebagai salah satu tujuan wisata di Kota Malang.

\section{d. Kampung Pelangi Wonosari dan Proyek Revitalisasi}

Siapa inisiator desain dekoratif Kampung Pelangi Wonosari, masih sumir. Suherdjoko (2017) dalam laporannya untuk The Jakarta Post, surat kabar berbahasa Inggris ternama di Indonesia, menyebutkan bahwa inisiator desain dekoratif kampung ini adalah Slamet Widodo, Kepala Sekolah sebuah sekolah menengah pertama, sekaligus warga di kampung ini. Sementara beberapa situs berita daring terkemuka menyebut Pemerintah Kota Semarang, dalam hal ini Walikota Semarang, Hendrar Prihadi yang menginisiasi desain dekoratif kampung ini (Permadi, 2017; Purbaya, 2017).

Pendapat paling rasional mungkin adalah yang diungkapkan oleh Istiana dan Khadiyanto (2018). Desain dekoratif Kampung Pelangi Wonosari, menurut mereka adalah dampak ikutan dari pembangunan tahap 1 proyek Revitalisasi Pasar Kembang Kalisari yang tepat berada di seberang kampung terpisah Kali Semarang. Penataan permukiman ini bukan proyek yang terencana dan tidak terdapat pada RTBL Kawasan Kali Semarang maupun DED segmen Pasar Kembang Kalisari. Istiana dan Khadiyanto (2018) menyatakan bahwa penataan permukiman terutama di RW III dan RW IV adalah tindakan spontan yang adalah inisiatif bersama warga dengan pemerintah kota. Hal ini dikonfirmasi oleh beberapa berita yang dipublikasikan oleh media daring dan cetak. 
Inspirasi tentang bagaimana konsep desain dekoratif Kampung Wonosari diambil, juga ada perbedaan. Walikota Semarang, Hendrar Prihadi mengatakan bahwa konsep desain dekoratif Kampung Wonosari terinspirasi dari Favela de Rio de Janeiro, Brazil yang juga dicat warna-warni (Purbaya, 2017). Pendapat berbeda muncul dari Slamet Widodo, salah seorang tokoh di Kampung Wonosari, yang menyebutkan bahwa ide dekoratif Kampung Wonosari adalah kampung warnawarni di Malang (Kampung Warna-warni Jodipan) dan Kampung Kali Code (Suherdjoko, 2017).

Terlepas dari perbedaan itu, yang pasti kampung warna-warni menjadi trend setelah sekitar seperempat abad dimulai oleh Kampung Kali Code. Yang menarik, pada sekitar tahun 2016 hingga 2017, sebuah peristiwa politik menjadi perhatian secara nasional; Proses Pemilihan Umum Kepala Daerah (Pilkada) Daerah Khusus Ibu Kota Jakarta (DKI Jakarta).

\section{e. Hingar Bingar Pilkada DKI Jakarta}

Pilkada DKI Jakarta 2017 adalah peristiwa politik yang penting dan mendapat perhatian banyak kalangan. Pelacakan pada portal pencari artikel ilmiah scholar.google.com menemukan adanya lebih dari 70 artikel terkait dengan peristiwa politik tersebut yang dipublikasikan pada tahun 2016 sampai dengan 2017.

Secara garis besar, peristiwa politik itu berlangsung sebagai beriku; tiga kandidat pasangan calon gubernur dan wakil gubernur berkontes dalam pilkada ini. Pasangan pertama adalah Agus Harimurti Yudhoyono berpasangan dengan Sylviana Murni (AHY-Sylvi), pasangan kedua adalah petahana, Basuki Tjahaja Purnama berpasangan dengan Djarot Syaiful Hidayat (Ahok-Djarot) dan pasangan ketiga adalah Anies Rasyid Baswedan berpasangan dengan Sandiaga Salahudin Uno (Anies-Sandi). 
Pilkada Pilkada DKI Jakarta 2017, berlangsung dua tahap, dimana pada tahap pertama pasangan kedua, Ahok-Djarot unggul meski hanya memperoleh 43\% suara. Pada tahap kedua pasangan kedua ini bahkan kalah oleh pasangan ketiga, Anies-Sandi yang memperoleh $58 \%$ suara pemilih. Perolehan suara pasangan kedua sangat jauh dibawah persepsi kepuasan publik terhadap kinerja pasangan ini sebagai petahana yang mencapai sekitar 74\%. Denny JA, peneliti dari Lingkar Survey Indonesia (LSI) kepada kompas.com, menyebutkan persepsi pribadi dan primordial pemilih terhadap pasangan Basuki T. Purnama - Djarot S. Hidayat menjadi faktor kekalahan mereka. (Carina, 2017).

Pemberitaan seputar Pilkada DKI Jakarta 2017, menurut Junaidi (2017) diriuhkan oleh media massa dengan pro kontra isu SARA akibat pidato Ahok di Kepulauan Seribu yang menyinggung ayat suci Al Quran. Perdebatan itu kemudian diamplifikasi melalui media sosial yang terdistribusi antar pribadi maupun kelompok. Penggunaan isu SARA yang masif, diakui oleh M Khoiruzadid Taqwa dkk. (2019), yang ditujukan kepada Ahok dinilai efektif untuk menurunkan jumlah pendukungnya.

Kontestasi Pilkada DKI Jakarta 2017, telah berlalu, dan menunjukkan keterbelahan masyarakat, tidak hanya di Jakarta namun berimbas jauh secara geografis maupun juga melintas peristiwa lain, yaitu Pemilu Presiden (Pilpres) 2019. Penggunaan isu SARA pada Pilkada DKI Jakarta 2017 dapat dirasakan hingga Pilpres 2019 (Taqwa, dkk, 2019; Sinaga, 2019).

\section{f. Desain Dekoratif sebagai Alternatif Perbincangan}

Di tengah hingar bingar dinamika politik DKI Jakarta yang berimbas pada perbicangan politik di tingkat nasional menjelang dan hingga Pilpres 2019, keberadaan Kampung Warna-warni Jodipan dan Kampung Pelangi Wonosari, menjadi alternatif perbincangan yang penting. Alasan pertama mengapa kedua kampung ini menjadi alternatif wacana penting adalah bahwa meski diinisiasi oleh 
kepentingan yang berbeda, desain dekoratif kedua kampung itu kemudian didukung bahkan diperkuat keberadaannya oleh pemerintah kota masing-masing.

Adalah fakta bahwa, kedua kota ini, konstelasi politiknya didominasi oleh partai-partai pengusung atau setidaknya berafiliasi dengan partai pendukung petahana, Ahok-Djarot yang berkontes di Pilkada DKI Jakarta 2017. Ir. H. Mochamad Anton, Walikota Malang, adalah seorang muslim berdarah Tionghoa yang didukung dan menrepresentasikan Partai Kebangkitan Bangsa (PKB). Sementara di Semarang, Hendrar Prihadi, SE. MM, Walikota Semarang adalah Ketua DPC (Dewan Pimpinan Cabang) Partai Demokrasi Indonesia Perjuangan (PDIP). Kedua partai ini menjadi adalah pendukung utama dan berada dalam satu kubu dalam kontestasi politik di Jakarta; yang kemudian pada Pilpres 2019 juga berada dalam satu koalisi.

Dukungan kedua pimpinan daerah di kota masing-masing pada desain dekoratif kampung, dapat dimaknai sebagai strategi menghadang wacana politik dari Jakarta yang berkembang hingga ke daerah-daerah. Warna-warni kampung sebagai hasil desain dekoratif itu menjadi perbincangan lain di luar riuhnya perbincangan politik di banyak media. Tentu saja dukungan media sosial, facebook, instagram, twitter, sangat membantu tersebarnya wacana alternatif ini.

Alasan kedua, mengapa desain dekoratif kampung di Malang dan Semarang menjadi penting sebagai wacana alternatif adalah dari aspek simboliknya. Pejalnya penggunaan isu SARA pada Pilkada DKI Jakarta 2017, dirasakan membelah masyarakat tidak hanya di Jakarta saja, namun juga melalui media sosial merangkak mempengaruhi masyarakat di luar Jakarta. Ringkasan mengenai hal itu dapat dilihat pada beberapa gambar berikut. 


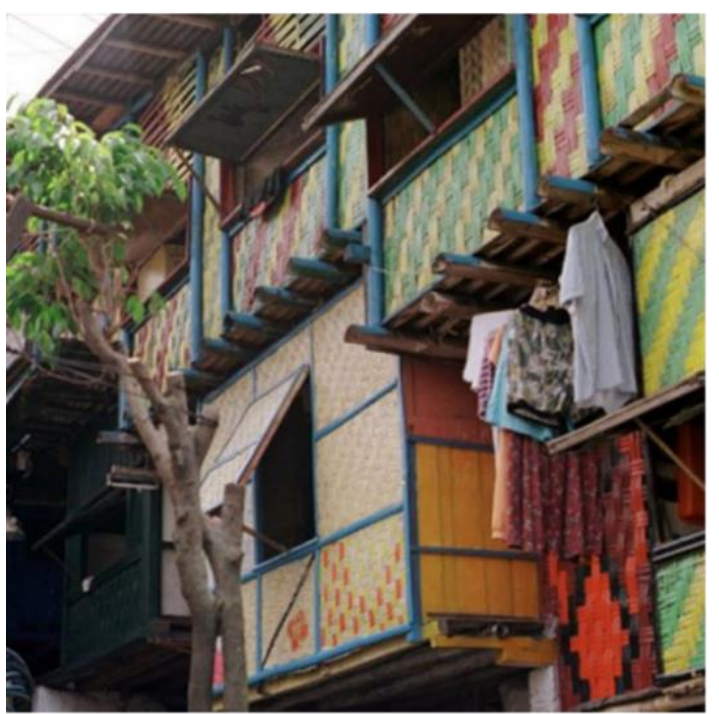

PROSES PRODUKSI

- Sederhana, vernakular, tidak tahan lama tetapi renewable.

- Dilaksanakan secara komunal, gradual dengan swadaya dan donasi tidak mengikat

PROSESINTERPRETASI

- Kemandirian dan harga diri warga kampung

- Melawan dengan memberi alternatif pemecahan masalah

\section{PRAKTIK WACANA}

- Logika pembangunan penguasa versus rekayasa teknis dan sosial memecahkan masalah lahan di bantaran sungai

Gambar 6. Analisis Kampung Kali Code, Yogyakarta

Sumber :analisis pribadi

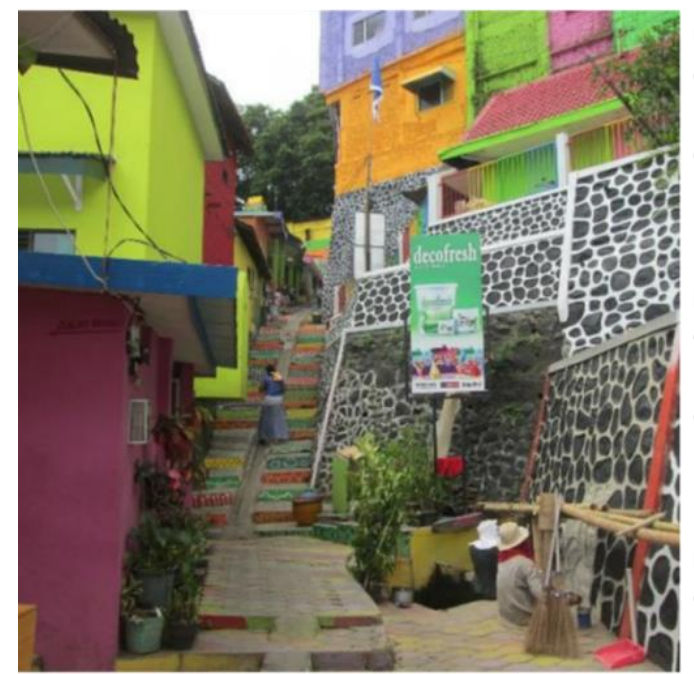

PROSES PRODUKSI

- Sederhana, tidak mengubah struktur sarana dan prasarana yang ada.

- Inisiasi top-down, berubah secara gradual dan dipandu Pemkot Malang menjadi destinasi wisata

PROSESINTERPRETASI

- Insiator yang menginspirasi warga kampung

- Diambil alih pemerintah kota pengelolaannya menjadi destinasi wisata

PRAKTIK WACANA

- Kreativitas kelompok dalam keragaman yang menjadi penggerak ekonomi lokal

Gambar 7. Analisis Kampung Warna-warni Jodipan, Malang

Sumber :analisis pribadi 


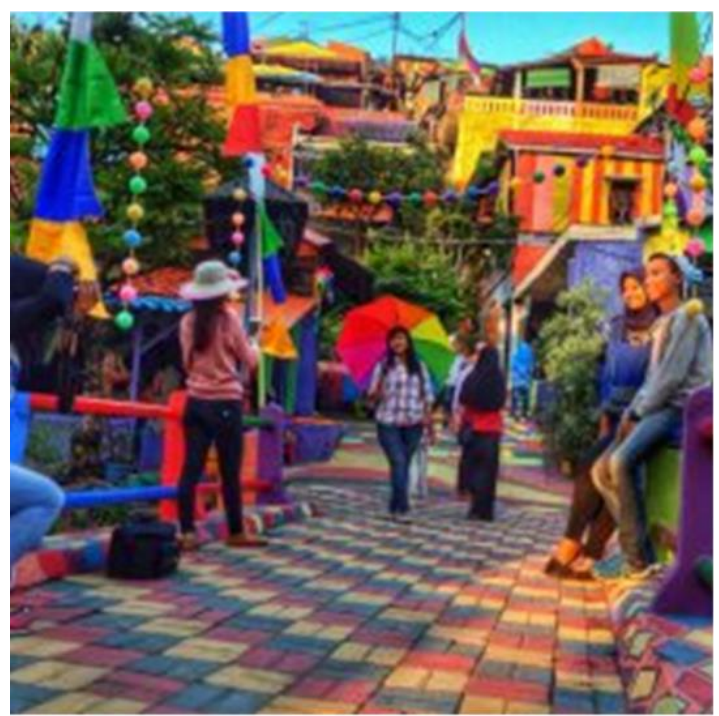

\section{PROSES PRODUKSI}

- Dampak ikutan penataan pasar tanaman hias

- Inisiasi setara antara pengelola proyek dan tokoh-tokoh warga, dipandu Pemkot Semarang

\section{PROSESINTERPRETASI}

- Inisiatif bersama pengelola proyek dan tokoh-tokoh warga

- Mempertontonkan keragaman dalam suasana dinamika politik Ibukota

\section{PRAKTIK WACANA}

- Kreativitas dalam keragaman sebagai simbol versus dinamika sosial politik yang berkembang

Gambar 8. Analisis Kampung Pelangi Wonosari, Semarang

Sumber :analisis pribadi

Suasana kebatinan masyarakat dirasakan seakan hanya ada hitam dan putih, kami dan kalian. Warna-warni kampung yang digunakan dalam dekorasi kampung menyimbolkan bahwa sejatinya dalam masyarakat itu tidak hanya hitam dan putih. Pilihan cat dekoratif warna-warni dari kedua kampung, kemudian digunakan untuk menunjukkan perbedaan, kemajemukan sebagai bagian dari nilai kebangsaan yang utama dan penting dari Indonesia.

\section{KESIMPULAN}

Desain, seringkali muncul dalam kaitannya dengan situasi politik, sosial dan kebudayaan. Kampung Kali Code, desain dekoratif kampungnya muncul sebagai tanggapan akan kebijakan Pemerintah Kota Yogyakarta, yang berencana menerapkan pendekatan normalisasi sungai-sungai di wilayahnya secara pejal dan seragam. Pendekatan yang bersifat top-down dan seragam ini diberi alternatif wacana dengan dekorasi dan penataan kampung yang lebih baik. 
Demikian juga ketika pada 25 tahun kemudian di Kampung Jodipan, Malang dan Kampung Wonosari, Semarang warganya beserta pemerintah kota, dengan inisiasi proyek yang berbeda, mempersolek diri. Wacana sosial-politik dari ibukota negara yang meriuhkan pemberitaan dan pembicaraan, mendapat alternatif dengan adanya desain dekoratif warna-warni kampung. Desain dekoratif kampung dipakai sedemikian rupa menjadi sarana untuk memperkuat nilai-nilai kebangsaan yang utama dan penting. Nilai-nilai yang dalam suasana kebatinan masyarakat sempat tergunjang karena pejalnya penggunaan isu SARA dalam wacana sosial-politik masyarakat.

\section{DAFTAR PUSTAKA}

Adiwibawa, B.A.P. 2017, September. Kampung Pelangi: The Reflection of National Value. Proceding at International Conference on Arts and Culture. pp 87-94

Aminudin, M. 2016. Ini Dia Mahasiswa Pencetus Kampung Warna-warni di Kota Malang. Tersedia di: https://news.detik.com/berita-jawa-timur/d3292071/ini-dia-mahasiswa-pencetus-kampung-warna-warni-di-kotamalang

Ayodiya, N.R.P. 2014. Model Kebijakan Permukiman Kampung Code Utara di Tepi Sungai Code. Jurnal Pembangunan Wilayah dan Kota. 10.1. pp 22-32

Carina, J. 2017. Survei LSI Denny JA: Dukungan untuk Ahok-Djarot 42,7 Persen, $\begin{array}{llll}\text { Anies-Sandi } 51,4 & \text { persen. } & \text { Tersedia }\end{array}$ http://megapolitan.kompas.com/read/2017/04/13/14583181/survei.Isi.de nny.ja.dukungan.untuk.ahok-djarot.42.7.persen.anies-sandi.51.4.persen.

Endriawan, D., Maulana, T. A., \& Sadono, S. 2017. Mural sebagai Media Pendidikan dan Pengabdian Masyarakat. dalam Seminar Nasional Seni dan Desain (pp. 482-485). Universitas Negeri Surabaya. 
Hamad, I. 2007. Lebih dekat dengan analisis wacana. Mediator: Jurnal Komunikasi, 8.2. pp 325-344.

Handayani, D.E. 2012. Kali Code Sungai Harapan Kita. Tugas Akhir. Fakultas IImu Sosial Universitas Negeri Yogyakarta. Tersedia di : http://eprints.uny.ac.id/23849/1/TUGAS\%20AKHIR\%20DEWI\%20ESTI\%20H ANDAYANI.pdf

Hanum, F. 2011. Kepemimpinan Komunitas Kali Code dalam Menggerakkan Modal Sosial. HUMANIORA. 16.1. pp. 22-44

Hudiyanto, R. 2007. Pahlawan yang Terlupakan: Pers Melayu, Etnik Tionghoa dan Nasionalisme di Kota Malang 1920-1950. Humaniora 19.3 pp. 215-223.

Ida, R. 2014. Metode Penelitian : Studi Media dan Kajian Budaya. Jakarta. Penerbit Prenada Media, 2014

Istiana, R dan Khadiyanto, P. 2018. Dampak Pembangunan Tahap 1 Revitalisasi Pasar Kembang Kalisari Berdasarkan Pendapat Masyarakat Sekitarnya. $\begin{array}{lllll}\text { Ruang. } & \text { 4.1. } & \text { pp. } & 66-74 . & \text { Tersedia }\end{array}$ http://ejournal2.undip.ac.id/index.php/ruang/

Junaidi, A. 2107. Media dan Keberagaman: Analisis Pemberitaan Media Daring Seputar Pemilihan Kepala Daerah DKI Jakarta. Jurnal Muara IImu Sosial, Humaniora, dan Seni 1.1.

Laksana, D.A.W. dan Adiwibawa, B. A. P. 2018. Mural dalam Paparan Media dan Pembelajaran Sosial bagi Masyarakat Kampung Kota. Jurnal Desain Komunikasi Visual, Manajemen Desain dan Periklanan - Demandia, vol. 3 no. 1. $\mathrm{pp} 46-56$. 
Legowo, S. H., Krisnadi, I. G. dan Sumartono, H. 2013. Dinamika Politik Rezim Orde Baru Di Indonesia Studi Tentang Kegagalan Konsolidasi Politik Rezim Orde Baru Pada Tahun 1990-1996. Publika Budaya 1.1 pp. 16-24.

Pakpahan, D. 2017. Gerakan Sosial ala Romo Mangun; Pengalaman Sejarah dan Kekinian. dalam St. Sularto, ed. Gerakan Sosial Romo Mangun. Jakarta. Penerbit Buku Kompas.

Permadi, G. 2017. Inisiasi Program Kampung Pelangi, Hendi Ikut Mengecat Rumah di Dukuh Wonosari. Tersedia di : http://jateng.tribunnews.com/2017/04/15/inisiasi-program-kampungpelangi-hendi-ikut-mengecat-rumah-di-dukuh-wonosari. diakses $14 / 12 / 2017$

Purbaya, A.A. 2017. Ini Cerita di Balik Kampung Pelangi Semarang yang Tengah Hits. Tersedia di: https://travel.detik.com/travel-news/d-3505071/inicerita-di-balik-kampung-pelangi-semarang-yang-tengah-hits. diakses $14 / 12 / 2017$

Puspitasari, A.W., Pandelaki, E.E. dan Setioko, B. 2013. Pengaruh Karakteristik Karya YB. Mangunijaya terhadap Karakter Visual Permukiman Bantaran Sungai; Studi Kasus Kampung Code Utara, Yogyakarta. Jurnal Teknik. 34.2 pp. 102-108.

Putra, Bramanta Octa Danu. 2013. Paradigma Pendekatan Ilmu Desain. Jurnal Rupa Rupa 2.2.

Radi, A. 1992 Technical Review Summary at Kampung Kali Cho-de, Yogyakarta, Indonesia. The Aga Khan Award for Architecture. 1117. IDA Tersedia di : http://www.akdn.org/sites/akdn/files/media/documents/AKAA\%20press\% 20kits/1992\%20AKAA/Kampung\%20Kali\%20Cho-de\%20-\%20Indonesia.pdf 
Sinaga, L.V. 2019. Tinjuan Sosial dalam Pencegahan Ujaran Kebencian dalam Media Sosial pada Pemilihan Presiden tahun 2019. JURNAL RECTUM: Tinjauan Yuridis Penanganan Tindak Pidana 1.1 pp. 10-17.

Sohirin. 2010. Melongok Dua Kampung Pengemis di Semarang. Tersedia di: https://nasional.tempo.co/read/news/2010/01/24/058221123/melongokdua-kampung-pengemis-di-semarang

Sudaryanto, dan Wibawa, Y.S. 2013. Sejarah Perkembangan Kota Semarang (Jawa Tengah) di Masa Lalu dan Dampak Kehadiran Polutan Nitrat Pada Airtanah di Masa Kini. Jurnal RISET Geologi dan Pertambangan. 23.1 pp. 27-39.

Suherdjoko. 2017. Colorful kampung becomes new tourist attraction in Semarang. Tersedia di: https://www.thejakartapost.com/travel/2017/05/09/colorfulkampung-becomes-new-tourist-attraction-in-semarang.html. diakses $22 / 6 / 2019$

Sunaryo, R.G. 2007 Mengikuti Langkah Pikir Romo Mangun: Sebuah Tinjauan Mengenai Metode Perancangan Arsitektur Yusuf Bilyarta Mangunwijaya. DIMENSI (Journal of Architecture and Built Environment) 35.1. pp-41.

Taqwa, M.K., Purwanto, R., Putra, Y.A., Sukma, Y.W., Raisya, N.T., Fatmala, W.D., Hidayah, N., Menawati, R.S., Asyifani, K. 2019. Analisis Perspektif Mahasiswa dalam Menyikapi Isu SARA Menjelang Pilpres 2019. Jurnal Analisa Sosiologi 8.1. pp. $18-34$

Taufiqurrahman. 2016. Warna-warni Kampung Jodipan, Destinasi Wisata Anyar $\begin{array}{llll}\text { Kota } & \text { Malang. } & \text { Tersedia }\end{array}$ https://www.jawapos.com/read/2016/09/48876/warna-warni-kampungjodipan-destinasi-wisata-anyar-kota-malang. diakses 9/3/2017 
Demandia, Vol. 4 No. 2 (September 2019)

Wahono, F. 2017. Garis Massa ala Y.B. Mangunwijaya. dalam St. Sularto, ed. Gerakan Sosial Romo Mangun. Jakarta. Penerbit Buku Kompas.

NN. 2016. Kampung Warna Warni di Kota Malang. Tersedia di https://www.indana.co.id/kampung-warna-warni-di-kota-malang/ 